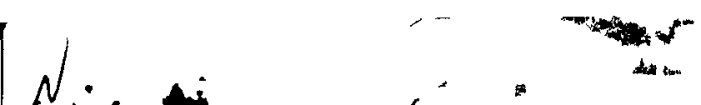

\title{
EMITTED AND DECAYED VALUES OF RADIONUCLIDES IN GASEOUS WASTES DISCHARGED TO THE ATMOSPHERE FROM THE SEPARATION FACILITIES THROUGH CALENDAR YEAR 1972
}

\author{
J. D. Anderson \\ Tank Farm Process Engineering \\ Waste Handling and Plutonium Finishing Process Engineering \\ Operations Technical Support Department
}

March 1, 1974

Operated for the Atomic Energy Commission by

60. Atlantic Richfield Hanford Company under Contract AT(45-1)-2130 


\section{DISCLAIMER}

This report was prepared as an account of work sponsored by an agency of the United States Government. Neither the United States Government nor any agency Thereof, nor any of their employees, makes any warranty, express or implied, or assumes any legal liability or responsibility for the accuracy, completeness, or usefulness of any information, apparatus, product, or process disclosed, or represents that its use would not infringe privately owned rights. Reference herein to any specific commercial product, process, or service by trade name, trademark, manufacturer, or otherwise does not necessarily constitute or imply its endorsement, recommendation, or favoring by the United States Government or any agency thereof. The views and opinions of authors expressed herein do not necessarily state or reflect those of the United States Government or any agency thereof. 


\section{DISCLAIMER}

Portions of this document may be illegible in electronic image products. Images are produced from the best available original document. 
TABLE OF CONTENTS

$\begin{array}{lc} & \text { Page } \\$\cline { 2 - 2 } \text {$\left.INTRODUCTION } & 3 \\ \text { DISCUSSION } & 3 \\ \text { TABLE I - KNOWN RADIOACTIVITY IN GASEOUS WASTE } \\ \text { DISCHARGED FROM THE SEPARATION FACILITIES }\end{array}\right)$




\title{
EMITTED AND DECAYED VALUES OF RADIONUCLIDES IN GASEOUS WASTES DISCHARGED TO THE ATMOSPHERE FROM THE SEPARATION FACILITIES THROUGH CALENDAR YEAR 1972
}

\author{
INTRODUCTION
}

Gaseous wastes from the chemical separations processing of spent reactor fuel elements and product finishing operations have been discharged to the atmosphere since 1944. Data on plutonium, beta, iodine, and uranium emissions for the twenty-nine years are provided. Table I presents the known radioactivity in gaseous wastes and Table II presents estimated radioactivity in gaseous waste where prime data were not available. Emission data are not included on gaseous wastes emitted from 200 Area facilities which are now under the jurisdiction of other Hanford contractors.

\section{DISCUSSION}

In October 1973, Atlantic Richfield Hanford Company was assigned the responsibility for a study to provide the emitted and decayed values of radionuclides in gaseous wastes discharged to the atmosphere from the separation and product finishing facilities through calendar year 1972 . The results of this study are included as Tables I and II in this document.

The first centralized documentation of radionuclide emissions in gaseous waste was initiated by ARHCO covering the calendar year 1968 and has been continued ever since. Other records which have been kept by other contractors - using different methods of documentation for beta, iodine, uranium, and plutonium emissions - have been located and used in this document. These documentations, along with the ARHCO documents, were combined to prepare the information presented in Table I of this document.

The data presented in Table II have all been estimated based upon various reports, documents, expertise, and operating experience. These estimates will be refined or changed should further studies reveal the existence of new information or data which have not come to the author's attention during this study. The methods of estimations are footnoted in the attached table.

This document does not include data on the radioactive inert gases, tritium, ${ }^{129} \mathrm{I}$, or ${ }^{14} \mathrm{C}$ which have been emitted from the various facilities.

Early-year experience with radioactive particles, radioactive iodine, radioactive ruthenium, and plutonium releases are summarized in the Appendix. 
It should be noted that there was insufficient time during this study to decay the beta activity. This task will be performed in the near future when programming time becomes available on the new CYBER computer. At that time, this document will be updated. 
TABLE I

KNOWN RADIOACTIVITY IN GASEOUS WASTE

DISCHARGED FROM THE SEPARATION FACILITIES

\begin{tabular}{|c|c|c|c|c|}
\hline YEAR & $\mathrm{Pu}(\mathrm{Ci})$ & Beta (Ci) & $i 31 I(C i)$ & $U(C i)^{4}$ \\
\hline 1949 & & & 4,640 & \\
\hline 1950 & & & 2,140 & \\
\hline 1951 & & & 18,700 & \\
\hline 1952 & & & 967 & .000008 \\
\hline 1953 & & 1,340 & 730 & .000006 \\
\hline 1954 & & 1,200 & 538 & .000004 \\
\hline 1955 & & 1,100 & 1,180 & .000002 \\
\hline 1956 & & 346 & 367 & \\
\hline 1957 & & 386 & 374 & \\
\hline 1958 & & 508 & 425 & \\
\hline 1959 & & 358 & 289 & \\
\hline 1960 & & 25.9 & 357 & \\
\hline 1961 & & 16.4 & 255 & \\
\hline 1962 & & $15.0^{1}$ & 122 & \\
\hline 1963 & & 4.7 & 138 & \\
\hline 1964 & & 11.0 & 79 & \\
\hline 1965 & & $6.3^{2}$ & 99 & \\
\hline 1966 & & $3.9^{3}$ & 71 & \\
\hline 1967 & .0353 & 1.51 & 30 & .000720 \\
\hline 1968 & .00938 & 1.67 & 5.62 & .000750 \\
\hline 1969 & $\leq .037$ & 4.29 & 1.58 & $<.000860$ \\
\hline 1970 & 5.161 & 1.93 & 0.492 & $<.001400$ \\
\hline 1971 & .0417 & 1.33 & 0.204 & .012400 \\
\hline 1972 & .00523 & 0.872 & 0.210 & .000090 \\
\hline TOTAL & .290 & $5,332.8$ & $31,503.1$ & .016240 \\
\hline DECAYED & .290 & & $<.000006$ & .016240 \\
\hline \multicolumn{5}{|c|}{$\begin{array}{l}{ }^{1} \text { The data from the } 234-5-Z \text { criticality incident are not included in this } \\
\text { table but may be found in Reference ( } 1 \text {. } \\
\text { 2Estimate is based upon the Purex emission for } 1965 \text {. } \\
\text { 3Estimate is based upon the emissions for } 1965 \text { and } 1967 \text {. } \\
\text { 4The data shown are only for emissions from the Uranium Oxide Plant. }\end{array}$} \\
\hline \multicolumn{5}{|c|}{$\begin{array}{l}\text { JD Anderson } \\
3 / 1 / 74\end{array}$} \\
\hline
\end{tabular}


TABLE II

ESTIMATED RADIOACTIVITY IN GASEOUS WASTE DISCHARGED FROM THE SEPARATION FACILITIES

\begin{tabular}{|c|c|c|c|c|}
\hline Year & $\mathrm{Pu}(\mathrm{Ci})$ & Beta (Ci) & $131 I(C i)$ & $U(C i)^{7}$ \\
\hline $\begin{array}{l}1944 \\
1945 \\
1946 \\
1947 \\
1948 \\
1949\end{array}$ & $\begin{array}{l}.00006^{1} \\
.032^{1} \\
.049^{1} \\
.178^{1} \\
.370^{1} \\
.0001^{1}\end{array}$ & $\begin{array}{r}1^{3} \\
406^{3} \\
470^{3} \\
610^{3} \\
890^{3} \\
290^{4}\end{array}$ & $\begin{array}{r}1,700^{6} \\
340,000^{6} \\
76,000^{6} \\
24,000^{6} \\
1,200^{6}\end{array}$ & \\
\hline $\begin{array}{l}1950 \\
1951 \\
1952 \\
1953 \\
1954 \\
1955 \\
1956 \\
1957 \\
1958 \\
1959\end{array}$ & $\begin{array}{l}.0004^{1} \\
.0006^{1} \\
.004^{1} \\
.007^{1} \\
.009^{1} \\
.010^{1} \\
.019^{1} \\
.030^{1} \\
.031^{2} \\
.038^{2}\end{array}$ & $\begin{array}{r}340^{4} \\
760^{4} \\
1,400^{5}\end{array}$ & & $\begin{array}{l}.000002^{5} \\
.000900^{8} \\
.001000^{8} \\
.001200^{8}\end{array}$ \\
\hline $\begin{array}{l}1960 \\
1961 \\
1962 \\
1963 \\
1964 \\
1965 \\
1966\end{array}$ & $\begin{array}{l}.047^{2} \\
.044^{2} \\
.038^{2} \\
.040^{2} \\
.048^{2} \\
.038^{2} \\
.034^{2}\end{array}$ & & & $\begin{array}{l}.001300^{8} \\
.008400^{5} \\
.001200^{8} \\
.001300^{8} \\
.001500^{8} \\
.001400^{8} \\
.001000^{8}\end{array}$ \\
\hline TOTAL & 1.067 & 5,167 & 442,900 & .019202 \\
\hline DECAYED & 1.067 & & $<.000001$ & .019202 \\
\hline
\end{tabular}

${ }^{1} A 11$ data for $B$ and $T$ Plants were estimated from studies performed in 1946. Z Plant data were estimated from process experience for 1959 through 1966. Redox and Purex data were estimated from Purex process experience for 1968, 1969 , and 1971.

${ }^{2}$ All data from Redox and Purex were estimated from Purex process experience for 1968,1969 , and 1971. The data for Z Plant were known.

${ }^{3}$ Estimates were based upon the number of curies charged using the emission ratio obtained in stack emission studies in 1946. Estimates were also included for the particle emission incidents.

HEstimates were based upon T Plant process experience for 1953, 1954, and 1955 and were applied to both B and T Plants.

${ }^{5} 0$ nly data for part of the year were found. The rest of the year was estimated from this data.

${ }^{6}$ Estimates were based upon reactor production calculations.

7The data shown are only for emissions from the Uranium Oxide Plant.

${ }^{8}$ Estimates were based upon the Uranium Oxide Plant emissions for 1967, 1968, and 1969.

JD Anderson

$3 / 1 / 74$ 


\section{REFERENCES}

(1) HW-77345 (unclassified), May 23, 1962, J. K. Soldat, "Recuplex Incident, April 7, 1962 - Emission of Fission Products from the 291-Z Stack."

The following documents are also pertinent to this document:

c HW-20332 (unclassified), February 16, 1951, A. G. Blasewitz, et al., "Decontamination of Dissolver Vent Gases at Hanford."

- HW-52803 (unclassified), October 28, 1957, M. W. McConiga and J. K. Soldat, "Radioactive Contamination in the Hanford Environs for the Period Apri1, May, and June, 1957."

Geneva Paper P/743-USA (unclassified), September 1958, B. V. Andersen,

et al., "Radiation Exposure to People in the Environs of a Major Production Atomic Energy Plant."

$\leftarrow$ HW-61676 (unclassified), August 27, 1958, B. V. Andersen, "Hanford Environmental Monitoring Annual Report - 1958."

$\angle$ HW-64371 (unclassified), May 9, 1960, R. C. Henle, et al., "Evaluation of Radiological Conditions in the Vicinity of Hanford for 1959."

C HW-68435 (unclassified), June 1, 1967, R. F. Foster and I. C. Ne7son, "Evaluation of Radiological Conditions in the Vicinity of Hanford for 1960."

$\angle$ HW-71999 (unclassified), March 1, 1962, R. F. Foster and I. C. Nelson, "Evaluation of Radiological Conditions in the Vicinity of Hanford for 1961."

L HW-76526 (unclassified), February 25, 1963, R. F. Foster and R. H. Wilson, "Evaluation of Radiological Conditions in the Vicinity of Hanford for 1962."

HW-80991 (unclassified), February 24, 1964, R. F. Foster and R. H. Wilson,

L "Evaluation of Radiological Conditions in the Vicinity of Hanford for 1963."

BNWL-90 (unclassified), July 1965, R. F. Foster and R. H. Wilson, "Evalua-

$\angle$ tion of Radiological Conditions in the Vicinity of Hanford for 1964."

L ARH-1187 (unclassified), March 26, 1969, D. L. Uebelacker, "Radioactivity in Gaseous Waste Discharged from the Separations Facilities During 1968."

ARH-1604 (unclassified), March 6, 1970, D. L. Uebelacker, "Radioactivity in Gaseous Waste Discharged from the Separations Facilities During 1969." 


\section{APPENDIX}

EARLY-YEAR EXPERIENCE

\section{Radioactive Particles}

The gaseous wastes generated from December 1944 to October 1948 were discharged unfiltered from the $B$ and $T$ Plant stacks to the atmosphere using the atmosphere to significantly dilute the radionuclides entrained in the gaseous streams. In late September 1947, the occurrence of contamination in the form of discrete radioactive particles on the ground in the vicinity of the separation plants was detected.

At the time of detection, it was thought that the contamination might have existed for several months prior to its discovery. By mid-october it had been established that the carrier particles were corrosion products from black iron in the stack fan ductwork. Particles were emitted at a rate of approximately $10^{7}$ to $10^{8}$ particles per month from each of the bismuth phosphate processing plants and observed deposition was one to ten percent of the emission. Highest observed surface concentration was 50 particles per square foot in isolated areas with activity ranging from 0.1 to 3 microcuries beta activity and up to 3,200 disintegrations per minute alpha activity. Principal radioactive contaminants were defined as cerium, yttrium, strontium, ruthenium, and cesium. Soon after discovery of the condition and during the period when the equipment was being replaced, personnel were provided with individual respirators which were monitored after each work day.

Although the emission of large and more serious particles was eliminated by the equipment replacements, numerous smaller particles continued to be emitted. This condition was successfully overcome by installing and diverting the stack effluent through a sand filter at $B$ and $T$ Plants prior to discharging the gaseous wastes to the atmosphere. The filters had a collection efficiency of greater than 99.5 percent and were installed on October 15, 1948 at T Plant and on 0ctober 30, 1948 at $B$ Plant. Subsequently, the U Plant facility was equipped with a sand filter. The Redox Plant, which was placed into service in January 1952 , was also equipped with a sand filter. The 234-5-Z Plant, which was placed into service in July 1949, has used both the high-efficiency particulate air filters and chemical warfare service filters. The Purex Plant, which was placed into service in January 1956, was equipped with fiberglass filters. It has been established that the various filter types are all approximately 99.95 percent efficient.

\section{Radioactive Iodine}

In the early days of operation, the data obtained from Oak Ridge on the evolution of 131 I during spent fuel dissolution were used as a basis for estimating the dilution necessary to reduce effluent gaseous 
activity from the stacks to less than Manhattan Project tolerance levels. Because of the war emergency, irradiated fuel cooling periods were of relatively short duration and, thus, 131 I emissions were appreciable (an estimated 80 percent of the dissolved 131I was emitted).

Installation of water scrubbers in B and T Plants in May 1948 removed an estimated 85 percent of the 131 I charged to the processing plants. These were replaced by silver reactors (October 26, 1950 at B Plant and December 12, 1950 at T Plant), which had a 131 I removal efficiency of greater than 99 percent when processing longer-cooled irradiated fuels. Installation of the silver reactors, together with longer cooling and process improvements, have successfuliy decreased 131 I emissions to less than one curie per year.

Radioactive Ruthenium

At least nine specific incidents or periods involving ruthenium emission have occurred since start up of the Redox Plant in January 1952. In addition, there are indications that ruthenium particles were released almost continuously until about early summer of 1954. Surveys inside the Redox exclusion area revealed contamination in the range of 0.1 millirad per hour to 800 millirads per hour near the base of the stack and, in most instances, ammonium nitrate crystals were associated with the activity. Process equipment changes were effected in the summer of 1954 which prevented further significant ruthenium emissions.

\section{Plutonium}

Since start up of the Hanford Atomic Products Operation in late 1944, incidents of atmospheric contamination by plutonium emission have been successfully averted by the use of efficient filters in the ventilation effluent systems of those buildings handling the more concentrated plutonium solutions. Tests prior to start up with methylene blue smoke indicated an efficiency of about 99.9 percent; however, subsequent performance during plant operations showed an efficiency of greater than 99.99 percent. There have been some within-building incidents of plutonium air contamination, but all have been of short duration and the contamination of surrounding environs has never been threatened. 